\title{
Importance of Quaternary research to society
}

\author{
Centre for Natural Hazard Research, Simon Fraser University, Burnaby, BC, Canada V5A 1S6.E-mail: jclague@sfu.ca
}

\begin{abstract}
The Quaternary Period, although only an instant in the 4.5 billion year expanse of geologic time, is disproportionately important because it is the interval during which humans evolved and because it includes the present. Events of the Quaternary are preserved in sediments, ice sheets, and landforms with a greater degree of completeness and temporal resolution than those of any earlier period of comparable length. Studies of these historical and environmental archives continue to provide the essential context that allows scientists to evaluate what is happening with Earth's climate today and to clarify our vulnerability to hazardous natural processes, for example earthquakes, tsunami, volcanic eruptions, floods, and landslides.
\end{abstract}

\section{Introduction}

The Quaternary Period is unique among all divisions of geologic time in that it includes the present day - the instant in the 4.5 billion years of Earth history that most preoccupies humans. Most humans have little sense or appreciation of recent history, and even less so of geologic history. As they look back in time, humans become increasingly disconnected from it. They have considerable interest in events of the past several years to several decades, less interest in events hundreds to thousands of years ago, and, with some exceptions, almost no interest in events millions or billions of years old. It is perhaps for this reason that humans relate to the research of Quaternary scientists, dealing as it does with processes and effects closest to their temporal frame of reference. This fact is not lost on Quaternary scientists - much of the intellectual energy in our community is channelled into societally relevant, earth science issues to which we can bring our skills to bear.

Geologists working far deeper in geologic time likewise have much to offer society, but they commonly are interested in processes and effects that are cumulative, spanning millions to tens of millions of years. The unavoidable incompleteness of the geologic record generally precludes detailed reconstructions of "old" events, at least on timescales that are relevant to most people. Quaternary scientists deal with sediments and landforms that are young, commonly more complete, and resolvable at decadal to centennial timescales.

This paper highlights and amplifies on these comments by discussing two of the key issues confronting humanity today-climate change and hazardous Earth processes. Because my space is limited, I can only touch on the many contributions that Quaternarists are making in even these two areas and not at all on their contributions to other important public issues. My goal is to convey the rapid advances that are being made by a diverse and growing group of scientists united under the umbrella of the "Quaternary".

\section{Climate Change}

$\mathrm{Al}$ Gore and the International Panel on Climate Change (IPCC) have moved climate change to the forefront of the public agenda. As $A n$
Inconvenient Truth so graphically depicts, the signs of a change in climate are ubiquitous and well known-warmer surface temperatures, shrinking glaciers, diminishing Arctic sea ice, rising seas, and ecosystems under stress, to name a few. The focus within the scientific community has been, and continues to be, on forecasting climate change caused by increases in atmospheric carbon dioxide, methane, and other greenhouse gases over the remainder of this century. The research is being done principally by atmospheric scientists using highly sophisticated computers and numerical models.

Climate models are only reliable, however, if they fully capture the incredible complexity of the climate system, which I would argue is not yet the case. Furthermore, the models must be validated with historic climate data and, where possible, with reliable proxy climate data that can be provided only by Quaternary scientists. Finally, Quaternary scientists are perhaps in the best position to explain to the public and policy makers that climate change is the norm, that natural phenomena drive climate change, and that it is essential to disentangle natural from human-induced changes in the climate system.

Critical contributions to understanding Earth's climate have been made by oceanographers studying deep-sea sediments and glaciologists working on long cores taken from the Greenland and Antarctic ice sheets. Beginning with the pioneering work of Emiliani (1955) and later that of Shackleton (1967), Dansgaard and Tauber (1969), and Shackleton and Opdyke (1973), Quaternary scientists came to recognize the close linkage between Earth's atmosphere and its oceans, the important role of ocean bottom water in redistributing energy on the planet, and the rapidity of changes in Pleistocene climate and sea level. Scientists documented major restructurings in climate that happened on timescales of decades, such as during the Younger Dryas interval (12,700-11,500 years ago) at the end of the Pleistocene (Broecker and Denton, 1990).

Insights into the Earth system provided by Quaternary oceanographers in the 1960s and 1970s encouraged scientists to exploit another climate proxy - the Greenland and Antarctic ice sheets. Late Quaternary oxygen-isotope records with annual to decadal resolution have now been obtained from ice cores at more than 100 sites in Greenland and Antarctica, as well as from ice caps in the Himalayas (Thompson et al., 1989), the Andes (Thompson et al., 1995) and on Mt Kilimanjaro in Africa (Thompson et al., 2002). These records have provided an unparallel window into Earth's climate extending back to nearly 800,000 years (Figure 1; Johnsen et al., 1972; Lorius et al., 1979; Dansgaard et al., 1982, EPICA Community Members, 2004; Siegenthaler et al., 2005; Sphani et al., 2005). The Greenland ice cores provide evidence for periodic cold events that last about 1,000 years and begin and end abruptly. Broecker and Denton (1990) referred to these events as Dansgaard-Oeschger oscillations. Their occurrence implies a series of extreme fluctuations in climate in the Northern Hemisphere, with beginnings and terminations occurring on short enough timescales to be relevant to people. The events highlight the sensitivity and rapid response of Earth climate to natural forcings, even if the causes are not yet fully understood. Glaciers in the subtropics and tropics are shrinking so fast that previously collected and archived ice cores may be the only direct record we have of them before the end of this century. Of particular note is the Kilimanjaro ice cap, which will likely disappear in the next decade (Thompson et al., 2002).

Analysis of trapped air bubbles in Greenland and Antarctic ice cores also has provided valuable insights into fluctuations in atmos- 

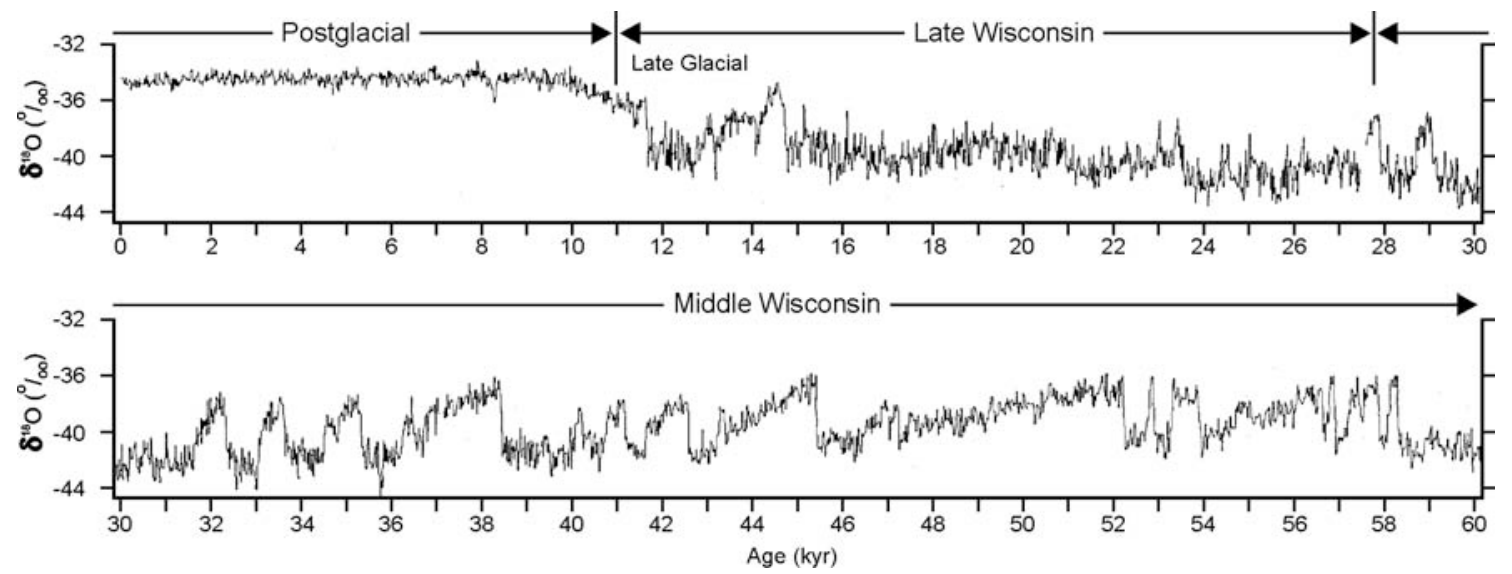

Figure $1 \delta^{18} \mathrm{O}$ record from GISP2 ice core, Greenland, for the $54{ }^{14} \mathrm{C} \mathrm{ka}$ (modified from Stuiver and Grootes, 2000, their Figure 1). The large and rapid changes in Northern Hemisphere climate during the late Pleistocene were driven by natural processes.

pheric carbon dioxide and methane over the past 800,000 years. The data have confirmed a lock-step relation between concentrations of these gases and climate (Petit et al., 1999), although what is driving what continues to be debated.

Fluctuations in isotope and gas concentrations in the Holocene parts of ice cores were initially overshadowed by the much larger swings of the Pleistocene. Recently, however, scientists have come to understand that Holocene climate has been far from benign - it has fluctuated sharply and significantly on timescales ranging from decades to millennia. The ice-core records are complemented by annually resolved reconstructions of Holocene climate provided by measurements of tree-ring widths (Mann et al., 1999). The proxy record of climate provided by old trees and instrumental climate data have elucidated the complex climate pattern of the past millennium, a period popularized by the term "Little Ice Age" (Figure 2). It is clear from the proxy record that climate fluctuated due to natural causes prior to the beginning of the Industrial Revolution, due perhaps to changes in volcanism or solar irradiation. Researchers, however, have pointed out that the warming of the past several decades is highly unusual and cannot be explained by natural forcing. They

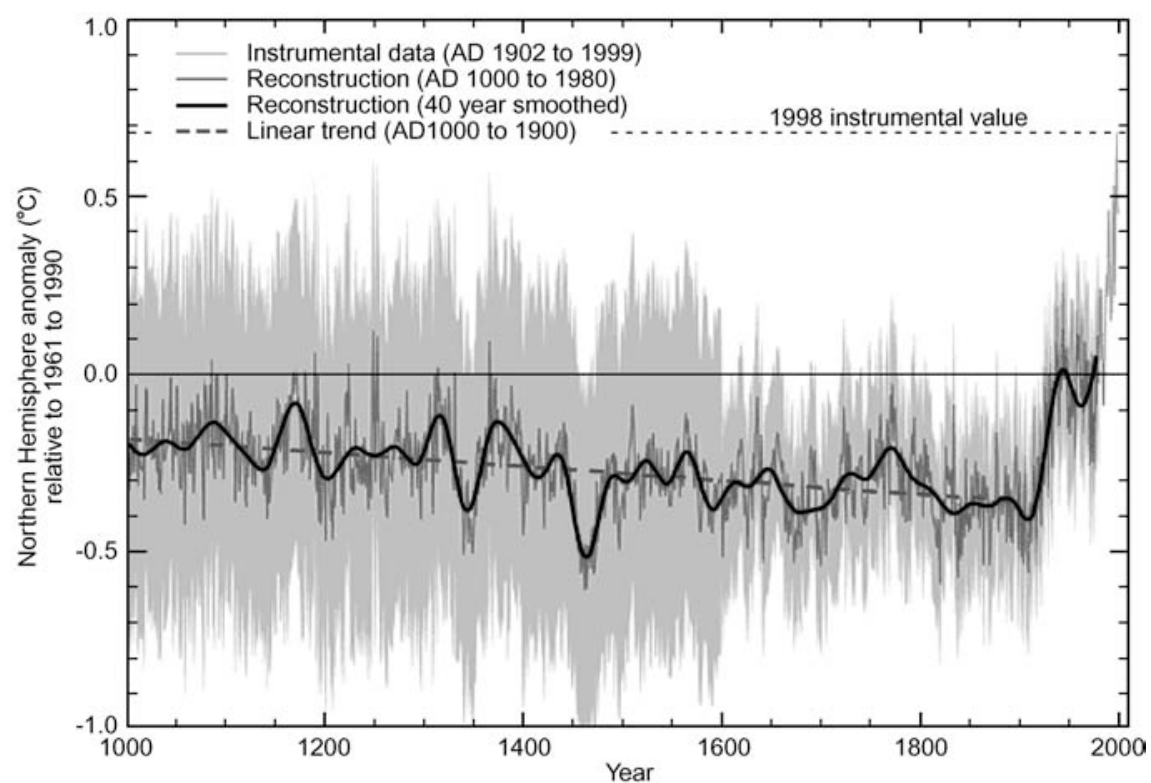

Figure 2 Millennial Northern Hemisphere temperature reconstruction based on treering data (blue) and instrumental data (red) from AD 1000 to 1999 (adapted from Mann et al., 1999). Smoother version of the Northern Hemisphere series (black), linear trend from $A D 1000$ to 1850 (purple-dashed) and two standard error limits (grey shaded) are shown. argue that the accelerating rise in atmospheric greenhouse gases has become a more important driver of climate change than natural ones.

An additional point of note in the intense research effort on past climates being made by Quaternary scientists is that it is inherently interdisciplinary. Like all large, societal issues, climate research is difficult and complex. It requires scientists able and willing to operate as teams, commonly comprising geologists, oceanographers, glaciologists, geographers, biologists, chemists, and many others. Quaternary scientists are perfectly positioned through their training and inclination to operate within such a framework.

\section{Natural hazards}

Earth is a dangerous place. Disasters resulting from "normal" Earth processes typically claim tens of thousands of lives every year and cause hundreds of billions of dollars damage to human works. Clearly, society has an interest in reducing this terrible toll. Much of what needs to be done to reduce risk from earthquakes, tsunami, landslides, volcanic eruptions, floods, severe storms, and other disasters lies outside earth science, within the domains of civil engineering and the social sciences. But earth scientists also have a role to play. Specifically, they are key to improving our understanding of the physical processes responsible for natural disasters and for providing reliable data on the frequency and magnitude of past events. In most parts of the world, instrumental and written records of past natural disasters are much too short to provide adequate data for the frequency-magnitude relations that are required to confidently forecast future disasters. Quaternary stratigraphy and landforms provide a wealth of information on most hazardous natural events In this section, I provide one example of the contribution Quaternary scientists are making to improving knowledge of a specific natural hazard-large earthquakes on the west coast of North America, notably in two areas - the Pacific Northwest and California.

Prior to the 1980s, our understanding of earthquake risk on the west coast of North America was based almost entirely on instrumental data that date back only to the late nineteenth century. Although clearly important, the instrumental record alone may provide a biased view of both hazards and risk.

Beginning with seminal work of Atwater (1987, 1992), geologists provided unequivocal lithostratigraphic and biostratigraphic evidence 

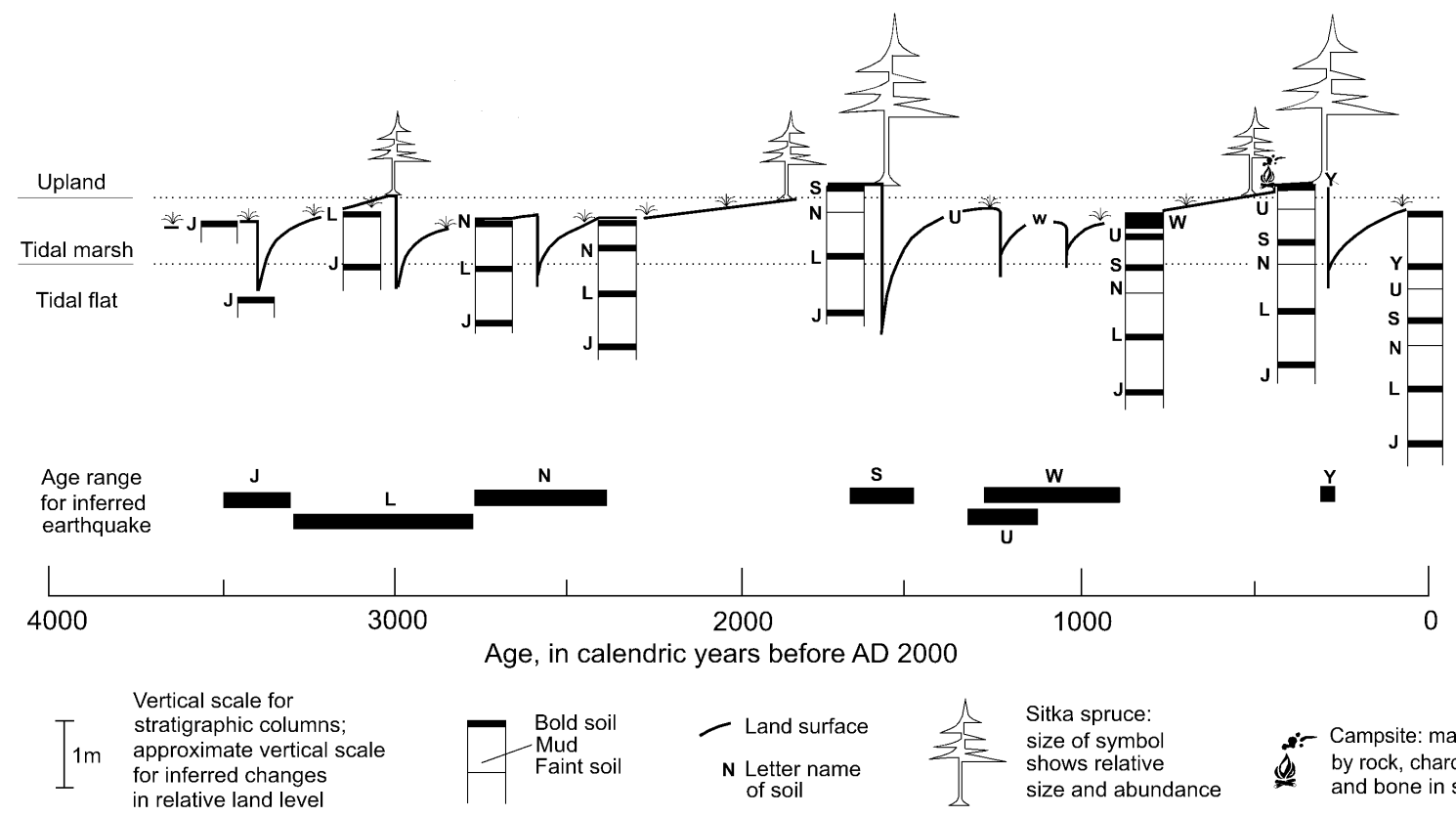

Campsite: marked
by rock, charcoal,

Figure 3 Effects of great earthquakes on tidal marsh stratigraphy over the past 4000 years in southern coastal Washington (adapted from Atwater and Hemphill-Haley, 1997). The earthquakes correspond to times of abrupt land-level change, when marshes dropped lower in the intertidal zone. The horizontal bars indicate the intervals in which the earthquakes occurred (95\% confidence interval) and are based on radiocarbon ages. Only the last of the seven earthquakes is precisely dated; it occurred on January $26,1700$.

for historically unprecedented, recurrent great $(\mathrm{M}>8)$ earthquakes and accompanying tsunamis at the Cascadia subduction zone, which extends along the Pacific coast from northern California to southern British Columbia (Atwater et al., 1995, Clague, 1997). The evidence includes distinctive couplets of thin marsh peat overlain abruptly by thicker tidal mud; layers of tsunami sand commonly separate these two lithologies. Plant macrofossils, diatoms, and foraminifera reveal up to $2 \mathrm{~m}$ of sudden land-level change at the peat-mud contacts, consistent with coseismic subsidence. Radiocarbon dating of fossil plants in growth position at the peat-mud contacts has provided a chronology of great subduction zone earthquakes extending back almost 4000 years (Figure 3). Study of tsunami sand layers in tidal marshes and low-lying coastal lakes has provided important insights into the size of tsunami triggered by Cascadia subduction zone earthquakes (Clague and Bobrowsky, 1994, Kelsey et al., 2005). These geologic studies have been complemented by geodetic and geophysical research that has provided new insights into strain accumulation along the subduction zone.

Through LIDAR (Light Detection and Ranging) surveys, trench investigations, and other studies, geologists also identified crustal faults in populated areas of the Puget Lowland of Washington State that slipped during large earthquakes in the Holocene, but not historically (Nelson et al., 2003, Karlin et al., 2004). Much similar work has been done to document the slip history of active faults in California, thus extending the instrumented record of seismicity and providing a much better basis for establishing future probabilities of earthquakes (Rubin et al., 1998, Dolan et al., 2000, Jing et al., 2006). The research combines geomorphic interpretation of fault traces with interpretation of offset Quaternary strata in trenches excavated along and across faults. The studies of Kerry Sieh and his students and colleagues (Sieh, 1984, Sieh et al., 1989) on offset strata in trenches across strands of the San Andreas fault in southern California stand out, because they were the catalyst for a huge effort by geologists to better understand earthquake risk in California, which in turn led to improvements in earthquake engineering and better public awareness of earthquakes. The contributions of geologists in extending earthquake histories, not only in western North America but in most other active orogens, have greatly improved understanding of seismic hazards and risk, and have more broadly elevated public awareness of earthquakes and their effects.

\section{Concluding remarks}

Earth has a 4.5 billion year history, of which the Quaternary Period is only 0.04 percent. Yet, the events of this brief interval are important to people. Our genus appeared during the Quaternary, and its evolution was strongly shaped by the large and abrupt changes in climate that caused the episodic growth and decay of Northern Hemisphere ice sheets. Quaternary sediments, glaciers, and landforms contain most of the proxy records of past climate and catastrophes that are relevant to us. Accordingly, Quaternary researchers are at the forefront of the scientific movement to provide information of value to the public and policy makers.

\section{Acknowledgements}

I am grateful to Brad Pillans for comments on a draft of the paper that contributed to its improvement.

\section{References}

Atwater, B. F., 1987, Evidence for Holocene earthquakes along the outer coast of Washington state: Science, v. 236, pp. 942-944.

Atwater, B. F., 1992, Geologic evidence for earthquakes during the past 2000 years along the Copalis River, southern coastal Washington: Journal of Coastal Research, v. 97, pp. 1901-1919.

Atwater, B. F., and Hemphill-Haley, E., 1997, Recurrence intervals for great earthquakes of the past 3500 years at northeastern Willapa Bay, Washington: U.S. Geological Survey Professional Paper 1576.

Atwater, B. F. and 15 others, 1995, Summary of coastal geologic evidence for past great earthquakes at the Cascadia subduction zone: Earthquake Spectra, v. 11, pp. 1-18.

Broecker, W. S., and Denton, G. H.,1990, The role of ocean-atmosphere reorganisations in glacial cycles: Quaternary Science Reviews, v. 9, pp. 305-343.

Clague, J. J. 1997. Evidence for large earthquakes at the Cascadia subduction zone: Earthquake Spectra, v. 35: 439-460.

Clague, J. J., and Bobrowsky, P. T., 1994, Tsunami deposits beneath tidal marshes on Vancouver Island, British Columbia: Geological Society of American Bulletin, v. 106, pp. 1293-1303. 
Dansgaard, W. S., and Tauber, H., 1969, Glacier oxygen 18 content and Pleistocene ocean temperatures: Science, v. 166, pp. 499-502.

Dansgaard, W. S., Clausen, S. J., Gundestrup, N., Hammer, C. U., Johnsen, S. F., Kristindottir, P. M., and Reeh, N., 1982, A new Greenland deep ice core: Science, v. 218, pp.1273-1277.

Dolan, J. F., Sieh, K., and Rockwell, T. K., 2000, Late Quaternary activity and seismic potential of the Santa Monica fault system, Los Angeles, California: Geological Society of America Bulletin, v. 112, pp. 1559-1581.

Emiliani, C., 1955, Pleistocene temperatures: Journal of Geology, v. 63, pp. 538-575.

EPICA Community Members, 2004, Eight glacial cycles from an Antarctic ice core: Nature, v. 429, pp. 623-628.

Jing, L-Z., Klinger, Y., Sieh, K., Rubin, C., and Seitz, G., 2006, Serial ruptures of the San Andreas fault, Carrizo Plain, California, revealed by three-dimensional excavations: Journal of Geophysical Research, v. 111, 33 pp.

Johnsen, S. J., Dansgaard, W., Clausen, H. B., and Langway, C. C., Jr., 1972, Oxygen isotope profiles through the Antarctic and Greenland Ice Sheets: Nature, v 235, pp. 429-434.

Karlin, R. E., Holmes, M., Abella, S. E. B., and Sylwester, R., 2004, Holocene landslides and a 3500-year record of Pacific Northwest earthquakes from sediments in Lake Washington: Geological Society of America Bulletin, v. 116, pp. 94-108.

Kelsey, K. M., Nelson, A. R., Hemphill-Haley, E., and Witter, R. C., 2005, Tsunami history of an Oregon coastal lake reveals a $4600 \mathrm{yr}$ recorde of great earthquakes on the Cascadia subduction zone: Geological Society of America, v. 117, pp. 1009-1032.

Lorius, C. L., Merlivat, J., Jouzel, J., and Pourchet, M., 1979, A 30,000 year isotope climatic record from Antarctic ice: Nature, v. 80, pp. 644-648.

Mann, M. E., Bradley, R. S., and Hughes, M. K., 1999, Northern Hemisphere temperatures during the past millennium: Inferences, uncertainties, and limitations: Geophysical Research Letters, v. 26, pp. 759-762.

Nelson, A. R., Johnson, S. Y., Kelsey, H. M., Wells, R. E., Sherrod, B. L., Pezzopane, S. K., Bradley, L.-A., Koehler, R. D., III, and Bucknam, R. C., 2003 Geological Society of America Bulletin, v. 115, pp. 1388-1403.

Petit J. R. and 18 others, 1999, Climate and atmospheric history of the past 420,000 years from the Vostok ice core, Antarctica: Nature, v. 399, pp. 429-436.

Rubin, C. M., Lindvall, S. C., and Rockwell, T. K., 1998, Evidence for large earthquakes in metropolitan Los Angeles: Science, v. 281, pp. 398-402.

Shackleton, N. J. 1967. Oxygen isotope analyses and Pleistocene temperatures reassessed: Nature, v. 215, pp. 15-17.

Shackleton, N.J. and Opdyke, N.D., 1973, Oxygen isotope and palaeomagnetic stratigraphy of equatorial Pacific core V28-238: Oxygen isotope temperatures and ice volumes on 105 and 106 year scale: Quaternary Research, v. 3, pp. 39-53.

Siegenthaler, U. and 10 others, 2005, Stable carbon cycle-climate relationship during the late Pleistocene: Science, v. 310, pp. 1313-1317.

Sieh, K., 1984, Lateral offsets and revised dates of large prehistoric earthquakes at Pallett Creek, Southern California: Journal of Geophysical Research, v. 89, pp. 7641-7670.
Sieh, K., Stuiver, M., and Brillinger, D., 1989, A more precise chronology of earthquakes produced by the San-Andreas Fault in southern-California: Journal of Geophysical Research, v. 94(B1), pp. 603-623.

Spahni, R. and 10 others, 2005, Atmospheric methane and nitrous oxide of the late Pleistocene from Antarctic ice cores: Science, v. 310, pp. 1317-1321.

Stuiver, M. and Grootes, P. M., 2000, GISP2 oxygen isotope ratios: Quaternary Research, v. 53, pp. 277-284.

Thompson, L. G., Mosley-Thompson, E., Davis, M. E., Bolzan, J. F., Dai, J., Yao, T., Gundestrup, N., Wu, X., Klein, L., and Xie, Z., 1989, Holocene-Late Pleistocene climatic ice core records from Qinghai-Tibetan Plateau: Science, v. 246, pp. 474-477.

Thompson, L. G., Mosley-Thompson, E., Davis, M. E., Lin, P.-N., Henderson, K. A., Cole-Dai, J., Bolzan, J. F., and Liu, K.-B., 1995, Late Glacial stage and Holocene tropical ice core records from Huascaran, Peru: Science, v. 269, pp $46-50$

Thompson, L. G., Mosley-Thompson, E., Davis, M. E., Henderson, K. A., Brecher, H. H., Zagorodnov, V. S., Mashiotta, T. A., Lin, P.-N., Mikhalenko, V. N., Hardy, D. R., and Beer, J., 2002, Kilimanjaro ice core records: Evidence of Holocene climate change in tropical Africa: Science, v. 298, pp. 589-593.

Wells, A., and Goff, J., 2007, Coastal dunes in Westland, New Zealand, provide a record of paleoseismic activity on the Alpine Fault: Geology, v. 35, pp. 731-734.

John J. Clague is Shrum Professor of Science at Simon Fraser University in Burnaby, British Columbia. He is Canada Research Chair in Natural Hazard Research and Director of SFU's Centre for Natural Hazard Research. John is a Fellow of the Royal Society of Canada, former President of the Geological Association of Canada, and Past-President of the International Union for Quaternary Research. He is recipient of the Geological Society of America Burwell Award, the Royal Society of Canada Bancroft Award, and the Geological Association of Canada's E.R.W Neale Medal and Logan Medal.

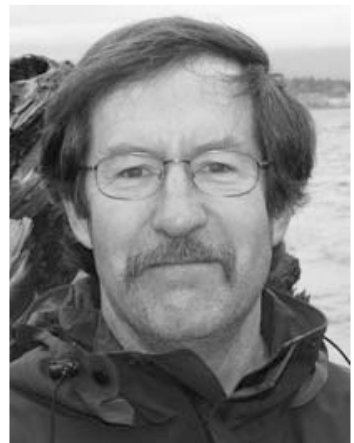

